\title{
ANALYSIS OF DOCUDRAMA HISTORY AND REFERENTIAL RECONSTRUCTION OF SANG KIAI MOVIES: ADAPTATION OF BIOGRAPHICAL HISTORIOGRAPHIC TEXTS TO BIOPIC FILM
}

\author{
Bambang A.K1, Nanik S. Prihatini², Sri Hastanto ${ }^{2}$, dan Dharsono ${ }^{2}$ \\ ${ }^{1}$ Institut Seni Indonesia (ISI) Surakarta \\ 2 Institut Seni Indonesia (ISI) Surakarta \\ ${ }^{3}$ Institut Seni Indonesia (ISI) Surakarta \\ E-mail : bamsliverpudlian@gmail.com
}

\begin{abstract}
This article discusses about the conception of adaptation of biographical historiographic texts into the medium text in the Sang Kiai film which is a type of historical docudrama film. Adaptation conception shows a transposition pattern of content from historical biographical narrative texts constructed into the text medium of Sang Kiai film. By conducting a study on the Sang Kiai film through approaches of adaptation and heuristic, hermeneutic, and internal criticism methodology has produced a pattern of referential reconstruction in the production of historical genre film texts, especially in the types of biopic films. The Sang Kiai film is a moving picture biography of the K.H. Hasyim Asy'ari figure who narrated historical facts about the nationalism of the founder of the Nahdlatul Ulama (NU) against the colonialist hegemony of Japanese and Allied fascist armies. Thus, the docudrama film which is positioned as a document of visualization of the historical facts about the past that is presented today through the reproduction of historical texts in the biopic film medium. The pattern of referential reconstruction shows that the biopic film of the Sang Kiai is a representation of the truth of the biographical facts of the K.H. Hasyim Asy'ari figure, although it was produced and presented through historical fiction film text
\end{abstract}

Keywords: adaptation, film, historical, docudrama, and biopic

\section{ABSTRAK}

Artikel ini membahas tentang konsepsi adaptasi (alih wahana) teks historiografi biografi ke medium teks pada film Sang Kiai yang merupakan jenis film dokudrama sejarah. Konsepsi adaptasi menunjukkan adanya pola transposisi konten dari teks sejarah naratif biografi yang dikonstruksikan ke dalam medium teks film Sang Kiai. Dengan melakukan kajian terhadap film Sang Kiai melalui pendekatan teori alih wahana dan metodologi heuristik, hermeneutik, dan kritik internal telah menghasilkan suatu pola rekonstruksi referensial dalam produksi teks film ber-genre sejarah, khususnya jenis film biopik. Film Sang Kiai merupakan film biografi atau biopic (biography moving picture) dari tokoh K.H. Hasyim Asy'ari yang menarasikan fakta-fakta historis tentang sikap kebangsaan dari kiai pendiri Nahdlatul Ulama (NU) melawan hegemoni kolonialis tentara fasisme Jepang dan Sekutu. Dengan demikian, film dokudrama yang diposisikan sebagai dokumen visualisasi atas fakta sejarah masa lampau yang dihadirkan pada masa kini melalui reproduksi teks sejarah dalam medium film biopik. Pola rekonstruksi referensial menunjukkan bahwa film biopik Sang Kiai merupakan representasi dari kebenaran fakta sejarah biografi tokoh K.H. Hasyim Asy'ari, meskipun diproduksi dan dihadirkan melalui bentuk teks film fiksi sejarah.

Kata kunci: adaptasi, film, dokudrama, sejarah, dan biopik 


\section{CAPTURE}

\section{PENDAHULUAN}

Perspektif historis perfilman Indonesia di rentang waktu periode tahun 1980-an hingga tahun 1990-an didominasi oleh produksi film-film ber-genre komedi, horor, kekerasan, dan seks sebagai arus utama industri media film. Genre produksi film tersebut merupakan bentuk aliran exploitation films. Exploitation films merupakan film yang bertujuan mencapai kesuksesan komersial semata dengan mengeksploitasi tema-tema sosial yang sensitif, mengerikan, namun tengah menarik perhatian (Ardanareswari, 2018:58). Saat memasuki tahun 2000-an, industri arus utama film-film Indonesia mengalami grafik peningkatan meskipun belum mampu menandingi hegemoni filmfilm produksi Hollywood. Fakta grafik peningkatan produksi film nasional bahwa pada tahun 2003 jumlah produksi film nasional masih meraup sekitar 11-15\% pangsa pasar film nasional, namun tahun 2005 meningkat menjadi 25\%. Bahkan, pada tahun 2007 film Indonesia telah mampu menjadi tuan rumah di negeri sendiri dengan persentase 55\% jika dibandingkan film Holywood (45\%), dari keseluruhan peredaran film di seluruh bioskop-bioskop nasional (Ayawaila dkk., 2013:94).

Arus utama industri film Indonesia pada tahun 2000-an ditandai oleh kemunculan film-film hasil produksi adaptasi atau ekranisasi dari novel yang memperoleh perhatian penonton hingga mencapai lebih dari 2 juta penonton film. Beberapa diantaranya menjadi film yang dikategorikan box office seperti film Eifel l'am in Love, Laskar Pelangi, dan AyatAyat Cinta, yang berhasil mencapai penonton 4 juta lebih. Film-film hasil alih wahana ternyata secara komersial memberikan dampak bagi industri perfilman menjadi trend di kalangan filmmaker. Di tengah trend produksi film hasil alih wahana dari karya sastra, kemudian hadir film berbasis pada sejarah biografi. Beberapa di antara film berbasis sejarah biografi tersebut menjadi film box office, seperti Habibie \& Ainun (Faozan Rizal, 2012) yang memperoleh penonton sampai 4 juta lebih. Fenomena trend film Indonesia dalam periodesasi tahun 2000an dengan film-film sejarah biografi tokoh Indonesia telah diidentifikasi pada tabel di bawah ini.

Tabel 1. Daftar produksi film biopik Indonesia tahun 2005-2018

\begin{tabular}{|c|c|c|c|}
\hline $\begin{array}{c}\text { Judul } \\
\text { Film/Tahun }\end{array}$ & $\begin{array}{c}\text { Biografi } \\
\text { Tokoh }\end{array}$ & Sutradara & Produksi \\
\hline GIE, 2005 & $\begin{array}{l}\text { Soe Hok } \\
\text { Gie }\end{array}$ & Riri Riza & $\begin{array}{l}\text { Miles } \\
\text { Films }\end{array}$ \\
\hline $\begin{array}{l}\text { Sang } \\
\text { Pencerah, } \\
2010\end{array}$ & $\begin{array}{l}\text { K.H. } \\
\text { Ahmad } \\
\text { Dahlan }\end{array}$ & $\begin{array}{l}\text { Hanung } \\
\text { Bramantyo }\end{array}$ & $\begin{array}{l}\text { Multivision } \\
\text { Plus }\end{array}$ \\
\hline $\begin{array}{l}\text { Soegija, } \\
2012\end{array}$ & $\begin{array}{l}\text { Mgr. } \\
\text { Albertus } \\
\text { Soegijapra } \\
\text { nata, SJ }\end{array}$ & $\begin{array}{l}\text { Garin } \\
\text { Nugroho }\end{array}$ & $\begin{array}{l}\text { Studio } \\
\text { Audio } \\
\text { Visual } \\
\text { Puskat } \\
\text { Yogyakart } \\
\text { a }\end{array}$ \\
\hline $\begin{array}{l}\text { Habibie \& } \\
\text { Ainun, } 2012\end{array}$ & $\begin{array}{l}\text { B.J. } \\
\text { Habibie }\end{array}$ & Faozan Rizal & $\begin{array}{l}\text { MD } \\
\text { Pictures }\end{array}$ \\
\hline $\begin{array}{l}\text { Sang Kiai, } \\
2013\end{array}$ & $\begin{array}{l}\text { K.H. } \\
\text { Hasyim } \\
\text { Asy'ari }\end{array}$ & $\begin{array}{l}\text { Rako } \\
\text { Prijanto }\end{array}$ & Rapi Films \\
\hline Soekarno, & Ir. & Hanung & MVP \\
\hline
\end{tabular}


Vol.10 No.2 Juli 2019

\begin{tabular}{|c|c|c|c|}
\hline 2013 & Soekarno & Bramantyo & $\begin{array}{l}\text { Pictures, } \\
\text { Mahaka } \\
\text { Pictures, } \\
\text { Dapur } \\
\text { Film }\end{array}$ \\
\hline $\begin{array}{l}\text { Merry } \\
\text { Riana: } \\
\text { Mimpi } \\
\text { Sejuta } \\
\text { Dolar, 2014 }\end{array}$ & $\begin{array}{l}\text { Merry } \\
\text { Riana }\end{array}$ & $\begin{array}{l}\text { Hestu } \\
\text { Saputra }\end{array}$ & $\begin{array}{l}\text { MD } \\
\text { Pictures }\end{array}$ \\
\hline $\begin{array}{l}\text { Jenderal } \\
\text { Soedirman, } \\
2015\end{array}$ & $\begin{array}{l}\text { Panglima } \\
\text { Besar } \\
\text { Jenderal } \\
\text { Soedirman }\end{array}$ & Viva Westi & $\begin{array}{l}\text { Padma } \\
\text { Pictures }\end{array}$ \\
\hline $\begin{array}{l}\text { Guru } \\
\text { Bangsa: } \\
\text { Tjokroamin } \\
\text { oto, } 2015\end{array}$ & $\begin{array}{l}\text { H.O.S. } \\
\text { Cokroamin } \\
\text { oto }\end{array}$ & $\begin{array}{l}\text { Garin } \\
\text { Nugroho }\end{array}$ & $\begin{array}{l}\text { Picklock } \\
\text { Production } \\
\text { Yayayasa } \\
\text { n Keluarga } \\
\text { HOS } \\
\text { Tjokroami } \\
\text { noto }\end{array}$ \\
\hline $\begin{array}{l}\text { Rudy } \\
\text { Habibie, } \\
2016\end{array}$ & $\begin{array}{l}\text { B.J. } \\
\text { Habibie }\end{array}$ & $\begin{array}{l}\text { Hanung } \\
\text { Bramantyo }\end{array}$ & $\begin{array}{l}\text { MD } \\
\text { Entertainm } \\
\text { ent }\end{array}$ \\
\hline $\begin{array}{l}\text { Athirah, } \\
2016\end{array}$ & $\begin{array}{l}\text { Athirah } \\
\text { (Ibunda } \\
\text { Yusuf } \\
\text { Kalla) }\end{array}$ & Riri Riza & $\begin{array}{l}\text { Miles } \\
\text { Films }\end{array}$ \\
\hline $\begin{array}{l}\text { Kartini, } \\
2017\end{array}$ & $\begin{array}{l}\text { R.A. } \\
\text { Kartini }\end{array}$ & $\begin{array}{l}\text { Hanung } \\
\text { Bramantyo }\end{array}$ & $\begin{array}{l}\text { Legacy } \\
\text { Pictures, } \\
\text { Screenpla } \\
\text { y Films }\end{array}$ \\
\hline $\begin{array}{l}\text { WAGE, } \\
2017\end{array}$ & $\begin{array}{l}\text { W.R. } \\
\text { Supratma } \\
\text { n }\end{array}$ & $\begin{array}{l}\text { John De } \\
\text { Rantau }\end{array}$ & $\begin{array}{l}\text { Opshid } \\
\text { Media } \\
\text { Untuk } \\
\text { Indonesia } \\
\text { Raya }\end{array}$ \\
\hline $\begin{array}{l}\text { Chrisye, } \\
2017\end{array}$ & Chrisye & $\begin{array}{l}\text { Rizal } \\
\text { Mantovani }\end{array}$ & $\begin{array}{l}\text { MNC } \\
\text { Pictures, } \\
\text { Vito } \\
\text { Global Visi }\end{array}$ \\
\hline $\begin{array}{l}\text { Sultan } \\
\text { Agung:Taht } \\
\text { a, } \\
\text { Perjuangan, } \\
\text { dan Cinta, } \\
2018\end{array}$ & $\begin{array}{l}\text { Sultan } \\
\text { Agung } \\
\text { Hanyakrak } \\
\text { usuma }\end{array}$ & $\begin{array}{l}\text { Hanung } \\
\text { Bramantyo }\end{array}$ & $\begin{array}{l}\text { Mooryati } \\
\text { Soedibyo } \\
\text { Cinema }\end{array}$ \\
\hline $\begin{array}{l}\text { A Man } \\
\text { Called } \\
\text { Ahok, } 2018\end{array}$ & $\begin{array}{l}\text { Basuki } \\
\text { Purnama } \\
\text { (Ahok) }\end{array}$ & $\begin{array}{l}\text { Putratama } \\
\text { Tuta }\end{array}$ & $\begin{array}{l}\text { The } \\
\text { United } \\
\text { Team of } \\
\text { Art }\end{array}$ \\
\hline
\end{tabular}

Realitas atas peristiwa sejarah masa lampau dapat dijadikan sebagai sumber ide produksi film bagi filmmaker secara kreatif dan estetis filmis dalam penggarapannya. Peristiwa sejarah selalu menghadirkan ruang-ruang bagi penafsiran, sehingga sejarah bersifat multitafsir, artinya kebenaran fakta sejarah dan pemaknaan atas peristiwa sejarah bergantung pada sudut pandang yang dipergunakan untuk memaknai peristiwa sejarah tersebut. Pada ruang inilah filmmaker hadir dalam karya-karya kreatif sinema, baik melalui medium kreatif film layar lebar, film pendek, film televisi yang disajikan baik dalam bentuk dokudrama, fiksi, maupun dokumenter.

\section{Peristiwa sejarah dapat diceritakan} kembali melalui berbagai perspektif yang relevan dan aktual sebagai sumber cerita produksi film (Armantono dan Paramita, 2017:68). Langkah awal, sineas dapat melakukan riset sejarah. Tujuan dari riset sejarah untuk menemukan materi cerita, terutama terkait untuk menemukan tokohtokoh dan peristiwa-peristiwa konkrit dari peristiwa sejarah masa lampau yang terjadi. Riset akan menemukan beragam persoalan dan peristiwa untuk diolah menjadi sebuah cerita. Biografi tokoh terkenal umumnya melahirkan peristiwaperistiwa besar yang inspiratif, sehingga seringkali dijadikan sebagai sumber cerita (Armantono dan Paramita, 2017:68-69).

Film biografi Indonesia era tahun 2000-an yang mengangkat narasi histori biografi tokoh besar (greatest man) salah satunya adalah film Sang Kiai. Film ini memenangkan penghargaan 4 Piala Citra tahun 2013, merupakan representasi sejarah biografi dari pendiri Nahdlatul Ulama (NU), yaitu K.H. Hasyim Asy'ari. 


\section{CAPTURE}

Peristiwa besar dalam narasi sejarah yang paling menonjol dalam catatan sejarah periodesasi revolusi kemerdekaan adalah fatwa Resolusi Jihad pada tanggal 22 Oktober 1945 yang menginspirasi peristiwa heroik pertempuran 10 Nopember 1945 di Surabaya.

Film merupakan media yang tidak saja memiliki fungsi seni hiburan, melainkan juga mengandung tatanan ideologi yang sarat dengan ikonik-ikonik dan simbolik-simbolik yang bersifat idealisme representatif dari mimetisme kehidupan suatu zaman. Realitas zaman dihadirkan dalam bentuk struktur naratif dan struktur dramatik film dengan merekonstruksi teks-teks naratif dan visualisasi dalam wujud suatu film, terutama film ber-genre sejarah, baik dari sisi penokohan pelaku, periodesasi waktu berlangsungnya peristiwa, maupun peristiwa sejarah yang terjadi.

Film-film ber-genre sejarah lebih mengedepankan idealisme estetika dan kemerdekaan kreativitas intelektualitas para filmmaker untuk merekonstruksi deskriptif naratif peristiwa-peristiwa monumentatif masa lampau dari suatu periodesasi zaman yang telah menjadi catatan sejarah. Film biopik, meskipun diproduksi dalam bentuk film fiksi ataupun dokudrama tetap harus berdasar pada fakta-fakta historis sebagai realitas dari suatu zaman yang dihadirkan dalam layar sinema Indonesia. Produksi film biopik tidak dapat mengabaikan ataupun melepaskan diri dari keberadaan faktafakta sejarah, terutama fakta-fakta sejarah dari subjek atau tokoh (llham, 2016). Film bertema sejarah tidak semata-mata merepresentasikan peristiwa dan waktu, melainkan juga merepresentasikan gambaran-gambaran pelaku atau tokoh sejarah yang kemudian divisualisasikan dalam wujud film biografi (biopik) sebagai teks historical memory (ingatan sejarah) (Iswarahadi, 2016). Hal ini memiliki relevansi dengan yang dikemukakan oleh Giles dan Middleton (1999:56-57) yang mendefinisikan representasi (to re-present), yang memiliki arti sebagai tulisan sejarah atau biografi yang dapat menghadirkan kembali kejadian-kejadian di masa lalu.

Film-film biopik (biografi moving picture) dalam khasanah perfilman Indonesia dikategorikan sebagai dokudrama (dokumenter drama). Dokumenter drama merupakan salah satu gaya bertutur film dokumenter. Film bergenre biopik merupakan bentuk dari dokudrama karena merekonstruksi peristiwa nyata yang direpresentasikan secara kreatif oleh filmmaker. Pada film dokudrama, pola kemasannya mengadaptasi pola penuturan film fiksi, yakni dengan menambahkan aspek dramatik pada alur penuturan. Film dokudrama biopik (biografi moving picture) lebih bebas merekonstruksi adegan masa lalu berdasarkan tafsirannya (Ayawaila, 
2008:171-175). Dengan demikian, produksi film dokudrama biopik keberadaan faktafakta sejarah dari subjek atau tokoh di masa lalu direkontruksi peristiwanya dengan penuturan cerita mempertimbangkan logika dari kronologi peristiwa. Kronologi adalah ilmu dasar sejarah (Grundwissenschaft) yang mengandung pengetahuan untuk menentukan waktu terjadinya suatu peristiwa dan menempatkan peristiwa-peristiwa tersebut secara tepat dalam urutan waktu (Alfian dalam Waridi dan Murtiyoso (ed), 2005:91).

Tujuan dari penulisan artikel ini adalah (1) untuk mengungkapkan dan mendeskripsikan fakta sejarah biografi K.H. Hasyim Asy'ari dengan representasi konten dalam struktur naratif film Sang Kiai, dan (2) mengkaji film Sang Kiai dengan menggunakan konsep Alih Wahana (Adaptasi) dari teks historiografi ke medium teks film untuk mendeskripsikan dan mengidentifikasikan pola transposisi antara fakta historis pada sejarah biografi K.H. Hasyim Asy'ari, yang terdapat pada sumber-sumber referensi teks naratif sejarah dengan aspek visualisasi yang dihadirkan dalam teks-teks visual film. Oleh karena itu, penelusuran terhadap kebenaran fakta-fakta sejarah biografi menjadi penting untuk menunjukkan bahwa film Sang Kiai benar-benar berdasar pada kebenaran fakta sejarah yang merupakan adaptasi atas representasi tokoh K.H. Hasyim Asy'ari. Ada relevansi teks antara teks fakta sejarah dengan konten teks film sebagai bentuk dari konsepsi adaptasi (alih wahana) dari teks sejarah menjadi teks film. Dengan demikian, film Sang Kiai sebagai komoditas tontonan bisa dipertanggungjawabkan secara substansi, baik dalam konteks sejarah maupun produk hiburan yang sarat dengan tuntunan dan tatanan kepada penonton. Film yang dihadirkan benar-benar merepresentasikan fakta historis yang sesungguhnya tanpa harus memanipulasi, dalam arti memutarbalikkan sejarah, fakta-fakta historis sebagai isi media sebagai tontonan film kepada publik (penonton) sebagai bagian strategis atas historical memory. Ketika memproduksi film biopik, filmmaker dalam melakukan rekonstruksi konten film harus tetap berpegang dan mengacu berdasarkan sumber-sumber sejarah.

\section{TINJAUAN PUSTAKA}

Robert A. Rosenstone mempublikasikan artikel ilmiah berjudul "The Historical Film as Real History", Journal Film-Historia, Vol. V, No.1 tahun 1995 membahas tentang film historis terkait dengan berbagai cara untuk membuat masa lalu di layar film. Bahasan mengenai penempatan sejarah dalam film menjadi beberapa kategori: sejarah sebagai drama, sejarah sebagai antidrama, sejarah tanpa pahlawan, sejarah sebagai tontonan, sejarah sebagai esai, sejarah pribadi, sejarah lisan, dan sejarah postmodern. Hubungan antara sejarah dengan film 


\section{CAPTURE}

terdapat pada kategori sejarah sebagai drama. Sejarah sebagai drama dapat dibagi menjadi dua kategori besar: (1) Film berdasarkan pada orang atau peristiwa yang dapat didokumentasikan, misalnya The Last Emperor, Gandhi, dan JFK; (2) Plot utamanya ber-setting sejarah, namun karakternya fiktif. Setting historisnya sebagai unsur intrinsiknya yang terdapat dalam cerita dan makna, contohnya film Dangerous Liaisons, The Molly Maguires, dan Black Robe.

Ismawati, Nurida, dan Warto mempublikasikan artikel ilmiah berjudul "Nilai-Nilai Nasionalisme Santri Dalam film Sang Kyai" di Jurnal AT-Tabsyir: Jurnal Komunikasi Penyiaran Islam, Vol. 4, No. 2 Desember 2016, membahas tentang nilainilai nasionalisme yang terdapat dalam film Sang Kyai. Nilai-nilai nasionalisme kaum santri (kaum sarungan), antara lain: (1) Nilai Kesatuan, nilai-nilai yang tercermin dari keinginan bersatu yang dimiliki oleh masyarakat dalam suatu bangsa karena persamaan senasib yang mereka rasakan, (2) Nilai Solidaritas, nilai-nilai kesetiakawanan yang bersifat kemanusiaan, dan (3) Nilai Kemandirian, nilai-nilai yang merupakan keinginan dan tekad untuk melepaskan diri dari belenggu kekuasaan yang absolut dan juga mendapatkan hak-haknya secara wajar. Ketiga nilai-nilai ini tercermin dari semangat nasionalisme kaum santri dalam film Sang Kyai.
Sandy Allifiansyah mempublikasikan artikel berjudul "Oposisi Biner Kesejarahan Indonesia Periode Revolusi Fisik (1945-1949) dalam film Seogija (2012) dan Sang Kiai (2013)", Semiotika: Jurnal Komunikasi, Vol. 11, No. 1 tahun 2017. Artikel ini mengkaji teks film sebagai teks fiksi dengan memposisikan cara berpikir oposisi biner terhadap teks kesejarahan di dalam media sinema. Historiografi visual yang disajikan dalam dua film biopik (Soegija dan Sang Kial) sama-sama menunjukkan kesamaan narasi. Kesamaan dalam menampilkan imajinasi historis yang tersaji lewat kemunculan tokoh-tokoh rekaan yang dimaknai secara simbolis.

Kajian dalam artikel ilmiah ini berbeda dengan kajian-kajian terdahulu, karena kajian ini mengkaji relevansi antara teks fakta-fakta sejarah biografi dari tokoh yang diangkat sebagai karakter utama dalam film dengan konten teks yang dihadirkan dalam medium film Sang Kiai. Pengkaji menelusuri teks-teks historiografi biografi K.H. Hasyim Asy'ari berdasar pada prinsip-prinsip penelitian dan penulisan sejarah yang berdasar pada tiga kategori penting, yaitu: tokoh, peristiwa, dan periode waktu. Kemudian, hasil penelusuran teks historiografi dikaji dengan menggunakan konsepsi teori alih wahana (adaptasi) untuk membuat simpulan tegas bahwa film Sang Kiai merupakan representasi histori biografi dari K.H. Hasyim Asy'ari. Penelaahan yang 
Vol.10 No.2 Juli 2019

dilakukan menemukan suatu pola transposisi, antara teks historiografi dengan teks film. Pola transposisi ini diidentifikasi berdasarkan pergeseran atau perubahan dari teks naratif sejarah menjadi teks audiovisual film. Sisi konten film, teridentifikasi bahwa pola transposisi merujuk kepada rekonstruksi referensial dalam proses produksinya, artinya adeganadegan yang ditampilkan dalam rangkaian sekuen-sekuen dalam struktur naratif dan struktur dramatik dalam film Sang Kiai tetap mengacu pada referensi histori, meskipun dalam realitas filmisnya terdapat rekonstruksi yang berdasar pada interprerasi dan imajinasi kreatif filmmaker sebagai bagian dari artikulasi estetika filmis.

\section{METODE}

Pembahasan dalam artikel ini bertolak dari dua pertanyaan besar dengan objek materiil film Sang Kiai, yaitu: (1) bagaimana fakta-fakta sejarah biografi Kiai Haji Hasyim Asy'ari direpresentasikan dan dikonstruksikan dalam visualisasi teks film biografi (biopics) Sang Kiai dalam struktur naratif film, dan (2) bagaimana hubungan transposisi antara teks historiografi biografi dengan medium teks film melalui konsepsi alih wahana pada film biografi Sang Kiai. Oleh karena itu, untuk mengkaji relevansi antara teks sejarah dengan teks audiovisual pada film Sang Kiai ini digunakan paradigma post-positivisme. Hal ini dilatarbelakangi oleh alasan, bahwa menurut pandangan post-posivitisme, kebenaran tidak hanya satu tetapi lebih kompleks, sehingga tidak dapat diikat oleh satu teori tertentu saja (Rahmat, 2009). Dengan demikian, metodologi untuk mengkaji teks film dan teks narasi sejarah dalm film Sang Kiai akan menggunakan metodologi kualitatif.

Penelitian kualitatif terdiri atas serangkaian interpretif deskriptif, meliputi data berupa kata-kata (kutipan berasal dari wawancara, catatan lapangan, percakapan), potongan gambar (capture image), foto, maupun rekaman, maupun bahan empiris seperti teks sejarah, studi kasus, pengamatan interaksional dan visual, dokumen pribadi dan dokumen resmi, dan bukan angka (Denzin dan Lincoln (ed), 2011:3; Denzin \& Lincoln, 1994:2; Upe dan Damsid, 2010:111; Rahmat, 2009).

Teknik berikutnya dalam pengumpulan data adalah studi pustaka dan studi arsip dengan berdasar pada kerangka teori heuristik dan kritik internal. Sjamsuddin (2016:55) berpendapat Heuristik (heuristic) sebuah kegiatan mencari sumber-sumber untuk mendapatkan data-data, atau materi sejarah, atau evidensi sejarah. Teori heuristik menerapkan metode tentang teknik atau cara-cara untuk menemukan sumber yang bisa didapat melalui studi kepustakaan, pengamatan secara langsung di lapangan (jika memungkinkan), 


\section{CAPTURE}

melalui interview untuk sejarah kontemporer. Sumber sejarah sebagai data dapat diperoleh dari kronik, annual, biografi, geneologi, memoir, catatan harian, sejumlah inskripsi tertentu, karya seni yang meliputi potret, lukisan-lukisan sejarah, patung, sejumlah film tertentu, kineskop, dan lain-lain (Sjamsuddin, 2016:62).

Operasionalisasi teknik pengumpulan data dalam penelitian ini terkait dengan studi pustaka, dilakukan dengan menemukan data-data berdasarkan fakta sejarah dengan menelusuri sumber-sumber referensi, baik primer maupun sekunder dari buku-buku sejarah (historiografi), jurnal ilmiah, makalah, berita di surat kabar yang membahas tentang teks naratif histori biografi. Karena dalam konteks film epik sejarah ataupun sejarah biografi, maka konten dan plot film harus benar-benar merujuk pada sumber sejarah, terutama pada tiga aspek penting tentang kebenaran sejarah biografi, yaitu: tokoh atau pelaku, peristiwa, dan waktu atau periode. Datadata sumber sejarah akan dibandingkan dengan visual-sinematik pada film biopik. Data-data tersebut untuk membuktikan keterkaitan alih wahana (adaptasi) antara historiografi biografi dengan film biopik yang dikaji.

Kritik internal sebagai bagian dari kritik sumber juga dilakukan terkait dengan teknik pengumpulan data. Kritik sumber dengan melakukan kritik internal untuk memperoleh kebenaran atau ketepatan (akurasi) dari sumber sejarah (Sjamsuddin, 2016:84). Hal ini merupakan bagian dari tahapan kegiatan verifikasi atau pengujian terhadap sumber-sumber sejarah pada data teks historiografi untuk mendukung bahasan kajian alih wahana (adaptasi) pada film biopik yang dikaji. Film biopik merupakan film epik sejarah yang harus berdasar pada fakta-fakta sejarah. Tugas kritik internal untuk menegakkan akurasi terhadap fakta-fakta sejarah (Sjamsuddin, 2016:92).

Pengumpulan data lainnya dilakukan dengan teknik wawancara mendalam terhadap informan atau narasumber yang terdiri atas pengamat film. Pendekatan Hermeneutika diperlukan untuk memaparkan, menafsirkan, dan menjelaskan data. Palmer (2016:8) mengatakan bahwa hermeneutika mengandung makna interpretasi (menafsirkan) atau pemahaman teks. Lebih lanjut Palmer (2016:40) menyatakan bahwa hermenutika merupakan penafsiran tekstual. Oleh karena itu, analisis data akan dilakukan dengan Analisis Tekstual, yaitu interpretasi yang dihasilkan dari teks. Interpretasi ini adalah proses ketika kita melakukan encoding sekaligus decoding terhadap tanda-tanda di dalam kesatuan sebuah teks yang dihasilkan (McKee dalam Ida, 2014:62-65),

\section{PEMBAHASAN}




\subsection{Fakta Sejarah Biografi K.H. Hasyim Asy'ari: Representasi Konten dalam Struktur Naratif Film Sang Kiai}

Film biopik yang dikategorikan sebagai film fiksi sejarah tetap mendasarkan pada kebenaran fakta sejarah, namun dalam bertuturnya tetap mempertimbangkan aspek dramatik dari tokoh yang menjadi karakter cerita film. Filmmaker pasti memilih peristiwa-peristiwa penting yang menarik pada diri tokoh cerita dan belum tentu ada peristiwa-peristiwa yang dialami oleh tokoh menjadi menarik dari sisi capaian dramatik, sehingga film akan membosankan dan tidak menarik penonton. Ada tokoh yang sangat inspiratif dalam hidupnya, akan tetapi ketika membaca sejarah hidupnya, tidak ada hal heroik dalam hidupnya sama sekali. Dengan demikian, pilihannya hanya ada dua, yaitu; (1) apabila filmmaker ingin benar-benar berpegang pada kebenaran sejarah hidupnya dari tokoh yang menjadi karakter film, konsekuensi logisnya akan didapatkan sebuah film yang peristiwaperistiwa dalam hidupnya sangat membosankan, (2) modifikasi konten cerita dengan melakukan dramatisasi yang berdasar pada interpretatif kreatif filmmaker dan imajinasi dengan tujuan agar garapan biopik tersebut menarik, baik secara struktur kronologis dan estetika filmisnya, sebagaimana dituturkan oleh Mohamad Ariansah (2017):

Film sebagai medium cerita

\begin{abstract}
audiovisual tidak bisa menceritakan keseluruhan konten cerita sejarah biografi yang panjang dari tokoh yang menjadi karakter film. Karena kadangkadang ada suatu peristiwa penting dalam kehidupan karakter tertentu yang tidak menarik sebagai drama. Hal itu mungkin krusial, tetapi ketika dianggap sebagai alat jalinan cerita itu tidak menarik dan itu bisa dihilangkan atau kadangkadang ditampilkan dengan cara lain. Karena bagaimanapun film biopik sebagai medium hiburan juga harus bicara tidak saja persoalan sejarah, melainkan juga tentang nilai-nilai dramatik.
\end{abstract}

Dengan demikian dalam produksi film biopik yang merupakan film dokudrama, para filmmaker diperbolehkan melakukan penambahan dramatisasi cerita tetapi tidak diperbolehkan memutar-balikkan fakta sejarah. Alih wahana yang baik tidak berarti memindahkan teks sejarah secara utuh menjadi biopik, tetapi memilih fakta-fakta sejarah yang penting dan melakukan reinterpretasi sesuai dengan karakter media audio-visual tanpa mengganggu nilai sejarahnya (Wiranegara, 2018).

Pemilihan kontens cerita dalam film biopik juga menjadi penting. Apalagi terkait dengan fakta sejarah. Umumnya pemilihan konten didasarkan pada peristiwa-peristiwa penting dari tokoh yang diangkat dalam film, sebagaimana yang dikemukakan oleh Marselli Sumarno (2017):

Film kisah. Film nyata yang difiksikan...sebagai pembuat, nomor satu akan dipertanyakan, You mau bicara apa? You mau mengatakan apa lewat Soegija, 
lewat Soekarno. Itu harus di dalam director statement sudah harus keluar. Misalnya, saya mau menghidupkan nasionalisme lewat gagasan-gagasan Soekarno atau saya mau meminjam Soegija untuk mengatakan bahwa ini dan ini bahwa kaum atau umat katolik pun juga berperan di dalam kemerdekaan. Nah, nomor satu gagasan dulu. Kan dari situ kita tahu sudut pandangnya itu. Kalau itu sudah benar, lalu dikembangkan ke treatment, lalu dikembangkan ke skenario, maka tadi saya bilang bungkusnya tadi memadai untuk suatu perimbangan antara apa yang mau dikatakan, apa yang mau dibutuhkan dan juga suatu apa ya, katakanlah strategi bahwa ingin menyaring, menjual, baru mengikuti itu, misalnya tentu dari sisi panjang itu mana yang dipilih, oleh episode-episode dalam hidup seseorang. Yang apa, yang boleh dikatakan yang menarik, yang manusiawi, lalu yang puncakpuncaknya.

Berdasar pada deskripsi yang disampaikan oleh para narasumber, pada film Sang Kiai terdapat adegan-adegan yang mengarah pada puncak-puncak peristiwa sejarah yang dialami oleh $\mathrm{K} . \mathrm{H}$. Hasyim Asy'ari. Beberapa momentummomentum yang menjadi peristiwa besar dari K.H. Hasyim Asy'ari, antara lain:

1) K.H. Hasyim Asy'ari ditangkap dan dipenjara oleh komandan Kempeitai dengan tuduhan terlibat dalam peristiwa Pabrik Gula Cukir.

2) K.H. Hasyim Asy'ari menolak melakukan Saikerei sehingga akibatnya mengalami penyiksaan oleh Kempeitai.
3) K.H. Hasyim Asy'ari ditunjuk oleh Seiko Shikikan sebagai Ketua Masyumi sekaligus Ketua Shumubu (Departemen Agama Bentukan Jepang).

4) K.H. Hasyim Asy'ari atas permintaan Bung Karno mengeluarkan Fatwa Resolusi Jihad karena kedatangan tentara Sekutu dan tentara Belanda yang ingin menguasai kembali Indonesia

Momentum yang menjadi puncakpuncak dari peristiwa dalam adeganadegan film Sang Kiai, merujuk pada representasi sejarah biografi dari K.H. Hasyim Asy'ari. Momentum-momentum sebagai puncak dramatik yang dialami oleh karakter K.H. Hasyim Asy'ari dalam film Sang Kiai diceritakan secara kronologis sesuai dengan urutan peristiwa sebagaimana fakta sejarahnya. Momentum peristiwa yang dialami oleh K.H. Hasyim Asy'ari tercermin dalam struktur naratif film Sang Kiai.

\subsection{Alih Wahana (Adaptasi) dan Rekon- struksi Referensial: Trasposisi Teks Historiografi ke Medium Teks Film Sang Kiai}

Pandangan terkait dengan alih wahana (adaptasi) disampaikan oleh Linda Hutcheon (2006:7-10).

Fenomena adaptasi r dapat
didefinisikan dari tiga perspektif
yang berbeda namun saling
terkait...adaptasi merujuk pada
proses dan produk. Pertama,


dilihat sebagai entitas atau produk formal, sebuah adaptasi adalah transposisi yang diumumkan dan diekstensif mengenai karya atau karya tertentu. "Transcoding" ini dapat melibatkan pergeseran medium (sebuah puisi ke sebuah film) atau genre (sebuah epik ke sebuah novel), atau perubahan frame, maupun karena konteks: menceritakan kisah yang sama dari sudut pandang yang berbeda, misalnya, dapat menciptakan interpretasi yang berbeda. Transposisi juga bisa berarti pergeseran ontologi dari yang nyata ke fiksi, dari catatan sejarah atau biografi hingga narasi atau drama fiksi. Kedua, sebagai proses penciptaan, tindakan adaptasi selalu melibatkan (re) interpretasi dan kemudian (re) kreasi atau penciptaan; Ketiga, dilihat dari perspektif proses penerimaannya, adaptasi adalah bentuk intertekstualitas: kita mengalami adaptasi (sebagai adaptasi) sebagai manuskrip atau bagian materi penulisan melalui ingatan kita terhadap karya lain yang beresonansi melalui pengulangan dengan variasi.

Adaptasi (alih wahana) dapat diartikan memindahkan cerita dari suatu media ke media yang lain. Oleh karena itu, terdapat tuntutan hal karya adaptasi harus sama dengan karya sumbernya, tetapi tuntutan ini sangat susah terpenuhi karena setiap media memiliki karakteristik atau ciri khas yang berbeda dengan media yang lain. Perbedaan media mengakibatkan perbedaan dalam cara menuturkan cerita. Adaptasi bukan semata-mata proses replikasi, tetapi di dalam adaptasi juga terkandung pengertian, antara lain tafsir ulang, evaluasi, revisi, improvisasi, inovasi, inisiatif, dan rekonstruksi (Hutcheon, 2006:8, Armantono dan Paramita, 2017:76).

Ayawaila (2008:45) berpendapat bahwa ada tiga hal yang perlu diperhatikan dalam menilik dokumenter sejarah, yaitu: periode (waktu peristiwa sejarah), tempat (lokasi peristiwa sejarah), dan pelaku sejarah. Di dalam film Sang Kiai, peristiwaperistiwa sejarah yang melibatkan K.H. Hasyim Asy'ari divisualisasikan secara dramatik, namun tetap berdasarkan datadata sejarah. Sineas Rako Prijanto secara cermat, melalui beberapa sekuenssekuens, menghadirkan sikap nasionalisme K.H. Hasyim Asy'ari, sehingga terbangun suatu konsepsi tentang reproduksi teks film sebagai catatan sejarah historical memory dari eksistensi K.H. Hasyim Asy'ari. Selain sebagai seorang ulama besar karismatik, K.H. Hasyim Asy'ari juga tokoh perjuangan kebangsaan (nasionalisme).

Relevansi antara teks historiografi terkait dengan tokoh (pelaku sejarah), periode (waktu peristiwa sejarah), lokasi (tempat terjadinya peristiwa sejarah), dan peristiwa sejarah pada film Sang Kiai adalah:

1. K.H. Hasyim Asy'ari ditangkap oleh militer Jepang dengan tuduhan terlibat dalam peristiwa Pabrik Gula Cukir

a. Data teks visual film 


\section{CAPTURE}
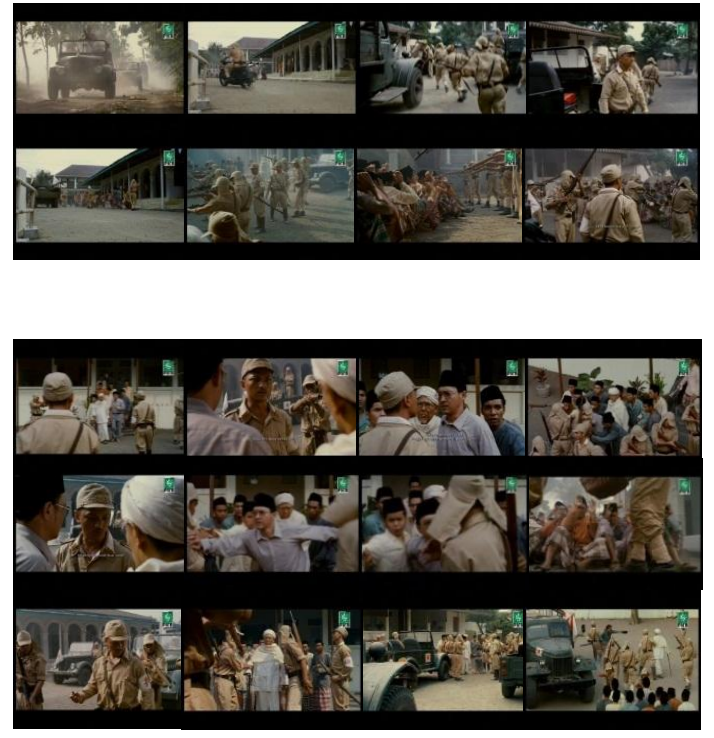

Gambar 1. Adegan film penangkapan K.H. Hasyim Asy'ari oleh tentara pendudukan militer Jepang pimpinan Kumakichi Harada di Pesantren Tebu Ireng karena dituduh terlibat dalam aksi pemogokan di Cukir

(Sumber: Sang Kiai, 2013, VTS_01_1, Time Code: 00:02:08-00:26:17).

\section{b. Data teks historiografi}

Lathiful Khuluq dalam bukunya berjudul

Fajar Kebangunan Ulama Biografi K.H.

Hasyim Asy'ari, menuliskan:

K.H. Hasyim Asy'ari tidak terkecuali mendapat perlakuan yang semena-mena dari pemerintah pendudukan Jepang. Beliau dipenjara selama empat bulan. K.H. Hasyim Asy'ari dituduh menjadi dalang kerusuhan di pabrik gula Jombang. Tuduhan ini jelas dibuat-buat oleh Jepang (Khuluq, 2007,124-125).

Abdul Mun'im DZ dalam artikel berjudul "Kisah Tebuireng, dari Mbah hasyim hingga Gus Dur", menulisan:

Hingga tahun 1940-an, jumlah kiai yang dilahirkan dari Pesantren Tebuireng terdata sebanyak 25.000 orang tersebar di seluruh Nusantara. Dalam penyelidikan Jepang semua kiai yang militan tersebut ditengarai sebagai fabrikaat Teuireng (gemblengan Tebuireng). Karena itu ketika melihat Mbah Hasyim tetap membangkang tidak mau melakukan saikere (penghormatan) pada bendera dan kaisar Jepang, maka pada April 1942 kiai ini ditangkap dan dipenjarakan oleh Jepang.

Berdasar pada data teks visual film dan data teks historiografi menceritakan serangkaian adegan penangkapan K.H. Hasyim Asy'ari yang dilakukan oleh Kempetai Jepang di pesantren Tebu Ireng. K.H. Hasyim Asy'ari dituduh terlibat dalam aksi pemogokan di Pabrik Gula Cukir. Adegan penangkapan diawali dengan iringiringan kendaraan militer Jepang yang memasuki jalanan pedesaan Tebuireng dan kemudian memasuki halaman pesantren. Tentara Jepang kemudian memaksa para santri untuk berkumpul di halaman pesantren di bawah todongan senjata serta tembakan senjata ke udara. Komandan Kempetai turun dari mobil sambil berteriak-teriak menanyakan K.H. Hasyim Asy'ari.

Adegan aksi kekerasan yang
dilakukan oleh Kempetai yang
menimbulkan kekacauan dan ketakutan para santri tersebut, membuat K.H. Hasyim Asy'ari dengan didampingi Wahid Hasyim, Yusuf Hasyim, Karim Hasyim, Baidlowi dan beberapa santri keluar dari rumah dan menemui komandan Kempetai. K.H. Hasyim Asy'ari menegur sikap komandan 
Vol.10 No.2 Juli 2019

Kempetai yang dianggapnya tidak sopan karena dianggap tidak sesuai dengan tata krama, namun komandan Kempetai tidak mempedulikan protes tersebut. Sebaliknya, dengan kasar Komandan Kempetai menyuruh anak buahnya untuk menangkap Kiai Hasyim Asy'ari. Saat tentara Jepang hendak menangkap Kiai Hasyim Asy'ari dihalang-halangi dan dicegah oleh Wahid Hasyim dan santri-santri lainnya, termasuk anak-anak Kiai Hasyim Asy'ari. Wahid Hasyim dengan berani mempertanyakan alasan penangkapan ayahnya. Komandan Kempetai menjawab dengan wajah marah di hadapan wajah Wahid Hasyim bahwa Kiai Hasyim Asy'ari dituduh telah menghasut rakyat pada aksi yang terjadi di Pabrik Gula Cukir. Tindakan tersebut dianggap sebagai tindakan pengkhianatan kepada pihak Jepang.

Adegan kemudian berlanjut dengan aksi komandan Kempetai yang segera memerintahkan anak buahnya untuk membawa Kiai Hasyim Asy'ari ke atas truk. Saat Kiai Hasyim Asy'ari digelandang oleh tentara Jepang, terdapat perlawanan dari para santri. Aksi tersebut membuat komandan Kempetai marah, kemudian menyuruh salah seorang tentaranya mengambil minyak tanah dan mengguyurkan ke tubuh para santri Tebuireng. Komandan Kempetai segera mengambil korek api dan menghidupkannya hendak membakar tubuh para santri yang telah diguyur minyak tanah. Akhirnya, Kiai Hasyim Asy'ari menyerah dan bersedia dibawa oleh Kempetai untuk ditahan dan dipenjara. Iring-iringan kendaraan militer Jepang tersebut pun meninggalkan Pesantren Tebuireng.

Fakta sejarah bersumber dari teks historiografi menceritakan penangkapan Kiai Hasyim Asy'ari oleh Kempetai karena dituduh terlibat dengan peristiwa aksi para buruh Pabrik Cukir. Kempetai menuduh Kiai Hasyim Asy'ari menghasut rakyat untuk melakukan pemberontakan dengan melakukan penyerangan Pabrik Cukir yang memang berada tidak jauh dari Pondok Pesantren Tebuireng. Pada masa penjajahan Jepang, banyak kiai-kiai yang ditangkap oleh Kempetai, termasuk K.H. Hasyim Asy'ari. Dengan demikian, berdasar teks historiografi terdapat relevansi antara teks fakta sejarah dengan teks visual dalam film Sang Kiai. Teks visual dalam film mendukung dan menguatkan sisi sejarah biografi K.H. Hasyim Asy'ari yang ketika masa-masa awal pendudukan tentara Jepang mengalami tindakan semena-mena. Hal ini dikarenakan pihak Pemerintahan Militer Jepang khawatir dengan pengaruh K.H. Hasyim Asy'ari sebagai ulama atau kiai besar di Jombang terhadap para santri dan masyarakat untuk menentang tentara Jepang. Akhirnya, atas alasan yang dibuatbuat tentara Jepang menangkap K.H. Hasyim Asy'ari di Pesantren Tebuireng. 


\section{CAPTURE}

Adegan pada layar film di saat komandan Kempetai hendak membakar para santri yang sudah diguyur minyak tanah, dari beberapa referensi teks historiografi, tidak ditemukan peristiwa sebagaimana yang dihadirkan dalam sekuens adegan cerita pada layar film tersebut. Adegan tersebut merupakan bentuk interpretasi imajinasi sineas yang menangkap suasana ketika penangkapan Kiai Hasyim Asy'ari. Adegan tersebut merupakan bentuk dramatisasi agar jalinan plot cerita menjadi menarik sebagai media tontonan. Karena film biopik Sang Kiai merupakan film dokudrama, maka sineas dimungkinkan untuk memberikan bumbu cerita dengan mendramatisasi peristiwa pada tokoh agar menjadi menarik.

$$
\text { Sekuen dengan adegan }
$$

penangkapan K.H. Hasyim Asy'ari oleh Kempetai dengan tuduhan terlibat peristiwa Pabrik Cukir dalam perspektif kajian adaptasi (alih wahana) merupakan transposisi dari medium teks narasi sejarah historiografi ke medium teks audiovisual film. Data teks visual dan data teks historiografi menunjukkan terjadinya transposisi, artinya terjadi pergeseran medium (sebuah teks sejarah ke sebuah film). Transposisi dari pergeseran realitas fakta ke fiksi, dari catatan sejarah atau biografi hingga narasi atau drama fiksi. Film dokudrama ini merupakan hasil dari rekonstruksi dan interpretasi sineas atas biografi sejarah tokoh K.H. Hasyim Asy'ari.
Dengan demikian, dari perspektif analisis adaptasi (alih wahana) dapat disimpulkan adanya hubungan rekonstruksi referensial. $\mathrm{Hal}$ ini dilatarbelakangi oleh alasan: terdapat relevansi tekstual antara data visual dan teks historiografi yang mengarah kepada konsepsi rekonstruksi adegan peristiwa yang melibatkan tokoh dan waktu terjadinya peristiwa sejarah pada diri tokoh K.H. Hasyim Asy'ari.

Adegan yang mengisahkan penangkapan K.H. Hasyim Asy'ari oleh Kempetai karena tuduhan terlibat dalam peristiwa Pabrik Gula Cukir mengacu pada referensi teks historiografi. Hubungan relevansi ini membuktikan adanya alih wahana atau adaptasi pada sekuen adegan tersebut di atas.

2. K.H. Hasyim Asy'ari menolak melakukan Saikirei sehingga menerima siksaan yang menyebabkan dengan kecacatan pada jemari tangannya.

a. Data teks visual film

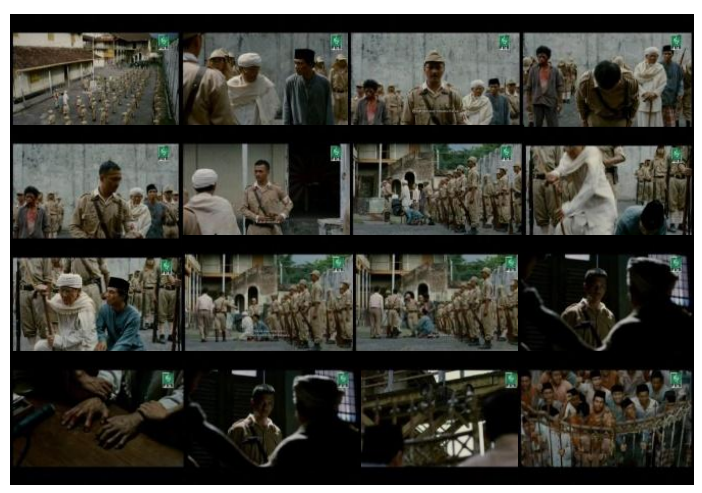

Gambar 2. Sekuens film ketika K.H. Hasyim Asy'ari menolak melakukan saekerei, meskipun dirinya harus mengalami siksaan oleh tentara Jepang (Sang Kiai, 2013, VTS_01_2, Time Code: 00:08:28-00:11:31). 
b. Data teks historiografi

Zuhairi Misrawi dalam artikelnya berjudul Hadratussyaikh Hasyim Asy'ari Moderasi,

Keumatan, dan Kebangsaan, menuliskan:

Penolakan Mbah Hasyim terhadap praktik saikerei, yaitu kewajiban memberikan penghormatan dengan cara membungkukkan badan ke arah Tokyo setiap pukul 07.00 sebagai simbol penghormatan kepada Kaisar Hirohito dan ketundukan kepada Dewa Matahari. Berdasarkan fakta sejarah, K.H. Hasyim Asy'ari menolak melakukan saikerei, atas sikap tersebut pihak Jepang merespons dengan tindakan represif. Selain memenjarakan, K.H. Hasyim Asy'ari juga disiksa hingga jari tangannya patah sehingga tidak bisa digerakkan (Misrawi, 2010,87-88).

Menurut Salahudin Wahid (dalam Miswari, 2010,xvi) bahwa ketika kebebasan agama terancam, perlawanan akan muncul seperti diperlihatkan pada penolakan untuk melakukan saikerei, yang memberi akibat penahanan beliau oleh pihak Jepang. Persoalan saikerei, K.H. Hasyim Asy'ari dengan tegas jelas-jelas menolak dan tidak akan melakukannya.

Abdul Mun'im DZ dalam artikelnya berjudul "Kisah Tebuireng, dari Mbah hasyim hingga Gus Dur", memaparkan:

Dalam penyelidikan Jepang semua kiai yang militan tersebut ditengarai sebagai fabrikaat Teuireng (gemblengan Tebuireng). Karena itu ketika melihat Mbah Hasyim tetap membangkang tidak mau melakukan saikere (penghormatan) pada bendera dan kaisar Jepang, maka pada April 1942 kiai ini ditangkap dan dipenjarakan oleh Jepang.

Data teks visual film dan data teks historiografi menceritakan serangkaian adegan K.H. Hasyim Asy'ari menolak melakukan saikerei ketika komandan Kempetai dan anak buahnya melakukan penghormatan kepada Kaisar dan Dewa Matahari bangsa Jepang. Kiai Hasyim Asy'ari, Kang Solichin, dan seorang tawanan Kempetai dipaksa mengikuti upacara tersebut, namun Kiai Hasyim Asy'ari dan Kang Solichin dengan tegas menolak melakukan saikerei. Komandan Kempetai marah lalu memerintahkan anak buahnya untuk memukuli dan menyiksa Kiai Hasyim Asy'ari. Sementara itu, di luar markas Kempetai para santri Tebuireng melakukan protes dengan berdemonstrasi menuntut pembebasan Kiai Hasyim Asy'ari, tiba-tiba dari mikrofon yang dipasang di luar markas Kempetai terdengar suara Kiai Hasyim Asy'ari yang merintih sambil beristighfar ketika Kempetai memukuli kedua belah jemari tangannya dengan palu besi. Begitu mendengar suara Kiai Hasyim Asy'ari yang sedang disiksa, para santri Tebuireng pun marah dan berusaha memaksa untuk masuk ke markas Kempetai dengan berusaha menjebol pintu gerbang.

Fakta sejarah yang bersumber dari beberapa teks historiografi menuliskan tentang penolakan Kiai Hasyim Asy'ari terhadap saikerei meskipun dirinya harus 


\section{CAPTURE}

dan mengalami siksaan oleh tentara Jepang. Akibat dari penyiksaan membuat tangan K.H. Hasyim Asy'ari mengalami kecacatan, yaitu jemari tangannya sulit digerakkan kembali. Saikerei adalah kewajiban memberikan penghormatan dengan cara membungkukkan badan ke arah Tokyo setiap pukul 07.00 sebagai simbol penghormatan kepada Kaisar Hirohito dan ketundukan kepada Dewa Matahari. Fakta sejarah menunjukkan bahwa karena menolak melakukan saikerei, K.H. Hasyim Asy'ari akhirnya dipenjarakan, berpindah-pindah dari penjara di Jombang ke Mojokerto, lalu ke Bubutan (Surabaya).

Relasi antara data teks visual dan data teks historiografi, dimana sekuen adegan penyiksaan terhadap K.H. Hasyim Asy'ari oleh Kempetai karena menolak melakukan seikirie hingga menyebabkan kecacatan jemari tangannya, dalam perspektif kajian adaptasi (alih wahana) itu merupakan transposisi dari medium teks narasi sejarah historiografi ke medium teks audiovisual film. Relasi itu menunjukkan terjadinya pergeseran medium (sebuah teks sejarah ke sebuah film). Transposisi yang terjadi merupakan pergeseran realitas fakta ke fiksi, dari catatan sejarah atau biografi hingga narasi atau drama fiksi. Film biopik ini, sebagai film dokudrama, menunjukkan hasil dari rekonstruksi dan interpretasi sineas atas biografi sejarah tokoh K.H. Hasyim Asy'ari. Perspektif analisis adaptasi (alih wahana) menunjukkan adanya hubungan rekonstruksi referensial.

Rekonstruksi referensial ini dilatarbelakangi oleh alasan, terdapat relevansi tekstual antara data teks visual dan data teks historiografi yang mengarah kepada konsepsi rekonstruksi adegan peristiwa yang melibatkan tokoh dan waktu terjadinya peristiwa sejarah dengan mengacu pada referensi sejarah sebagai sumber sineas untuk melakukan rekonstruksi adegan tersebut dalam layar film. Rekonstruksi yang ditunjukkan dengan adegan menyangkut tokoh (pelaku peristiwa), tempat peristiwa, dan waktu atau periode dari peristiwa fakta sejarah penyiksaan K.H. Hasyim Asy'ari oleh Kempetai tersebut mengacu pada referensi teks historiografi.

3. K.H. Hasyim Asy'ari Mengikuti Latihan Kiai dan Ditunjuk Menjadi Ketua Masyumi dan Shumubu oleh Seiko Sikikan

a. Data teks visual film

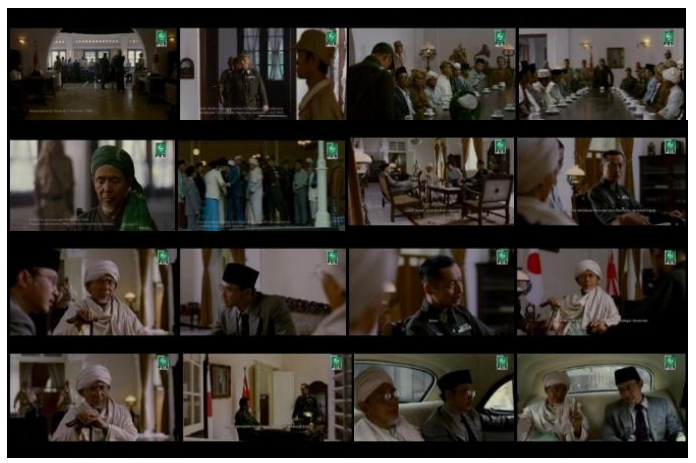

Gambar 3. Adegan film ketika pimpinan Tentara Pendudukan Jepang menunjuk K.H. Hasyim Asy'ari sebagai Ketua Masyumi sekaligus Shumubu dan 
terlibat dalam Latihan Kiai yang bertujuan untuk mendukung pemerintahan militer Jepang

(Sumber: Sang Kiai, 2013, VTS_01_3, Time Code:00:05:23-00:06:10)

b. Data teks historiografi

Zuhairi Misrawi dalam harian Kompas, menuliskan:

Fakta sejarah menunjukkan bahwa pemerintah Jepang memberi kepercayaan kepada Mbah Hasyim untuk memimpin Shumubu, semacam kantor agama tingkat nasional. Karena kantor Shumubu ada di Jakarta, dalam praktik, beliau diwakili oleh K.H.A. Wahid Hasyim (Salahudin Wahid, dalam Misrawi, 2010,xv). Pada tahun 1943, Kiai Hasyim diangkat sebagai Kepala Shumubu atau Kantor Urusan Agama Pusat, yang perannya sebagai Departemen Agama pada masa sekarang. samping itu, ia juga diangkat sebagai pemimpin Majelis alIslami A'la Indonesia (MIAI), kemudian ditunjuk sebagai pemimpin Masyumi (Misrawi, 2010,82).

Adapun Ali M Haidar dalam bukunya berjudul Nahdatul Ulama dan Islam di Indonesia, menuliskan:

Pada awal tahun empat puluhan mempunyai dampak membaiknya kedudukan kalangan Islam...penguasa Jepang kemudian mengalihkan perhatian kepada kalangan Islam. Selain reorganisasi kantor agama yang dibuka sampai ke daerah-daerah, juga latihan ulama oleh pihak Jepang dan pendirian Masyumi suatu federasi organisasi Islam. Latihan diselenggarakan secara berkala mulai pertengahan tahun 1943 melibatkan kurang lebih 60 orang ulama setiapkali angkatan...Mata pelajaran latihan antara lain dasar perang Asia Timur Raya, tujuan tentara Dai Nippon, sejarah perjuangan agama Islam di Indonesia, ilmu kesehatan, perindustrian, perhubungan, agama, dan pengetahuan umum (Haidar, 1998:100).

Lathiful Khuluq dalam bukunya berjudul Fajar Kebangunan Ulama Biografi K.H.

Hasyim Asy'ari, menuliskan:

$\begin{array}{lrr}\text { NU telah menjalin } & \text { kerjasama } \\ \text { bersama Jepang } & \begin{array}{r}\text { dengan } \\ \text { menduduki }\end{array} \\ \text { menerima tawaran } & \text { Kementerian } \\ \text { jabatan } & \text { Kemang } \\ \text { Agama...Pemerintah } & \text { Jepang } \\ \text { memang berusaha menarik }\end{array}$
dukungan dari kekuatan-kekuatan anti-Belanda dengan jalan mendekati umat Islam. Untuk melaksanakan politik tersebut, pemerintah Jepang mengundang 32 ulama, termasuk K.H. Hasyim Asy'ari, K.H. Mahfudz Shiddiq, dan K.H. A. Wahid Hasyim, pada suatu jamuan penghormatan bagi mereka di Jakarta. Pada pertemuan ini, kepala pemerintahan militer Jepang, Gunseikan, minta maaf kepada umat Islam mengenai kebrutalan polisi militer Jepang yang menurutnya disebabkan mereka kurang memahami budaya umat Islam. Setelah pertemuan ini, pemerintah Jepang agak mengendorkan kebijakannya dan bahkan menghapuskan kewajiban saikeirei (Khuluq, 2007,127).

Data teks visual film dan data teks historiografi menceritakan adegan ketika pemerintahan militer Pendudukan Jepang mengadakan pertemuan untuk membahas kegiatan Latihan Kiai dengan mengundang 32 kiai dari Jawa dan Madura yang diselenggarakan di Istana Gubernur 


\section{CAPTURE}

Batavia pada tanggal 7 Desember 1942. Pertemuan tersebut dihadiri secara langsung oleh Letjen Kumaichi Harada selaku pimpinan Saiko Sikikan. Pada kesempatan tersebut Letjen Kumaichi Harada menyampaikan permohonan maaf atas perilaku tentara Jepang kepada para kiai. Latihan Kiai diadakan pada tanggal 1 Juli 1943 yang juga diikuti oleh Kiai Hasyim Asy'ari.

Pada tanggal 24 Oktober 1943 Jepang membubarkan MIAI (Majelis Islam Ala Indonesia) dan mendirikan Masyumi (Majelis Syuro Muslimin Indonesia) di bawah pimpinan K.H. Hasyim Asy'ari. Penunjukan terhadap Kiai Hasyim Asy'ari bertujuan untuk mendukung keberadaan Dai Nippon di Indonesia. Pimpinan Tentara Pendudukan Jepang di Jawa menunjuk K.H. Hasyim Asy'ari sebagai Ketua Masyumi sekaligus Shumubu. Fakta sejarah semasa pemerintahan militer Jepang, K.H. Hasyim Asy'ari ditunjuk menjadi pemimpin Shumubu dan Masyumi. Hal itu dilakukan karena pemerintah militer Jepang menganggap bahwa Shumubu yang dipimpin oleh Husein Djajadiningrat dan Masyumi pimpinan Kiai Hasyim Asy'ari seringkali berbeda pandangan dalam mendukung pemerintah Jepang. Oleh karena itu, pemerintahan militer Jepang kemudian menunjuk K.H. Hasyim Asy'ari yang merupakan ulama besar dan memiliki jaringan kiai di Jawa hingga Madura serta memiliki ribuan santri, untuk menjadi pimpinan Shumubu sekaligus Masyumi. Selama perjalanan di dalam mobil, Wahid Hasyim menanyakan sikap Kiai Hasyim Asy'ari terhadap penunjukan pemerintah Pendudukan Militer Jepang tersebut. Kiai Hasyim Asy'ari menjawab menerima dan menyetujui penunjukan tersebut agar bisa memperjuangkan Indonesia, melalui Shumubu bisa mengambil kebijakan yang tidak merugikan rakyat.

Fakta historis ini pun dihadirkan dalam visualisasi film Sang Kiai, pemerintah militer Jepang merangkul para kiai dengan tujuan utamanya untuk memperoleh dukungan terhadap kolonialisme Jepang di Indonesia. Sekuen berupa adegan latihan kiai dan penunjukan K.H. Hasyim Asy'ari sebagai Ketua Shumubu dan Masyumi oleh Saiko Sikikan, dalam perspektif kajian adaptasi (alih wahana) merupakan transposisi dari medium teks narasi sejarah historiografi ke medium teks audiovisual/ film. Terjadi pergeseran medium, dari teks sejarah ke sebuah film, dari realitas fakta ke fiksi, dari catatan sejarah atau biografi ke narasi atau drama fiksi. Film biopik, meskipun berdasar sumber sejarah biografi, dalam praktik produksinya lebih sebagai film dokudrama di mana dilakukan rekonstruksi dan interpretasi sineas atas biografi sejarah, khususnya sejarah tokoh K.H. Hasyim Asy'ari.

Dengan demikian, analisis adaptasi (alih wahana) menunjukkan bahwa sekuen 
adegan film latihan kiai dan penunjukan Kiai Hasyim Asy'ari sebagai Ketua Masyumi dan Shumubu oleh Saiko Sikikan mengalami pola transposisi, yaitu pergeseran medium dari teks narasi fakta sejarah ke medium teks film dokudrama. Oleh karena itu, dapat disimpulkan adanya hubungan rekonstruksi referensial. Adanya relevansi tekstual di antara data teks visual dan data teks historiografi yang mengarah kepada konsepsi rekonstruksi adegan peristiwa yang melibatkan tokoh dan waktu terjadinya peristiwa sejarah. Sejarah sebagai sumber referensi bagi sineas dalam melakukan rekonstruksi adegan ke dalam layar film ini.

4. Kedatangan Sekutu di Surabaya yang dipimpin oleh Brigadir Jenderal AWS Mallaby dan K.H. Hasyim Asy'ari Mengeluarkan Fatwa Resolusi Jihad 22 Oktober 1945.

a. Data teks visual film

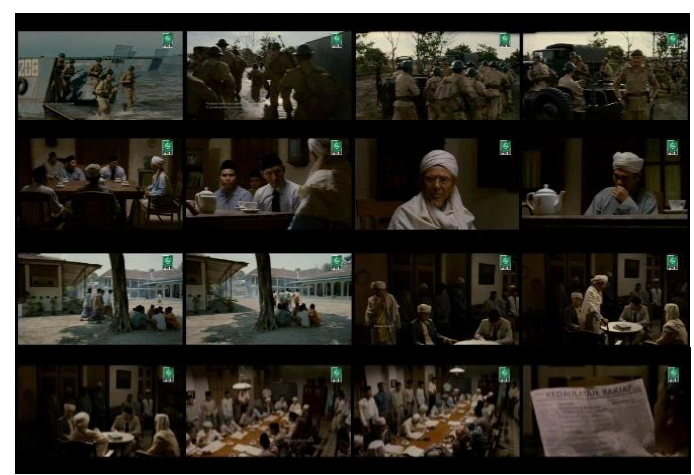

Gambar 4. Adegan Brigadir Jenderal Mallaby pimpinan tentara Sekutu mendarat di pantai luar Surabaya. K.H. Hasyim Asy'ari mengeluarkan Fatwa Resolusi Jihad tanggal 22 Oktober 1945 yang dipublikasikan melalui Koran Kedaualatan Rakyat (Sumber: Sang Kiai, 2013, VTS_01_3, Time Code: 00:19:30 - 00:21;14) b. Data teks historiografi

Lathiful Khuluq dalam bukunya berjudul Fajar Kebangsaan Ulama: Biografi KH. Hasyim Asy'ari, menuliskan

Di mana pada tanggal 22 Oktober 1945, delapan minggu setelah Proklamasi Kemerdekaan Indonesia, terjadi peperangan di Surabaya. Untuk memobilisir dukungan umat Islam, KH. Hasyim Asy'ari mengeluarkan fatwa untuk tetap mempertahankan kemerdekaan RI (Lathiful Khuluq, 2007:143).

Penulis lain, Zuhairi Misrawi dalam artikel berjudul Hadratussyaikh Hasyim Asy'ari Moderasi, Keumatan, dan Kebangsaan, memaparkan:

Diterbitkannya Resolusi Jihad oleh PBNU pada tanggal 22 Oktober 1945 oleh K.H. Hasyim Asy'ari bersama sejumlah ulama yang memberi fatwa landasan keagamaan bagi perjuangan fisik melawan tentara Belanda yang akan membonceng kehadiran tentara Sekutu yang akan menerima kekuasaan dari tentara Jepang (S. Wahid dalam Zuhairi Misrawi, 2010:xvi).

Pada tanggal 22 Oktober 1945, Kiai Hasyim bersama sejumlah ulama di kantor NU di Jawa Timur mengeluarkan sebuah resolusi jihad untuk melawan pasukan gabungan Belanda dan Inggris. Seluruh umat Islam terbakar semangatnya untuk melakukan perlawanan pada tanggal 10 November 1945. Peristiwa tersebut dikenal dengan Hari Pahlawan Nasional (Zuhairi Misrawi, 2010:90).

Sedangkan Said Agil Siroj yang artikelnya berjudul "Menjaga Marwah 


\section{CAPTURE}

Ulama" dalam buku Nasionalisme dan

Islam Nusantara, menuliskan:

Fatwa Jihad Kiai Hasyim Asy'ari pada 22 Oktober 1945, mampu menggerakkan ribuan santri dan pemuda untuk bertempur demi tegaknya NKRI, pada 10 Nopember 1945. Rekaman sejarah inilah yang tidak pernah muncul dalam narasi besar pengetahuan warga negeri ini. Di tengah gegap-gempita untuk mengisi kemerdekaan dan semangat reformasi, ternyata kiprah santri dan NU bagi kemerdekaan Indonesia makin hari makin dilupakan orang. Untuk itu, momentum Resolusi Jihad Kiai Hasyim Asy'ari perlu dijadikan sebagai penanda sejarah untuk kebangkitan santri (Siroj dalam Ubaid dan Bakir, 2015b:58).

Selain itu, Said Agil Siroj juga menuliskan:

Jadi, umat Islam wajib hukumnya membela tanah air. Bahkan haram hukumnya mundur jika berhadapan dengan penjajah dalam radius 94 kilometer (jarak ini disesuaikan dengan diperbolehkannya qashar shalat). Di luar radius dianggap fardhu khifayah. Fatwa yang ditulis dengan huruf pegon itu kemudian digelorakan Bung Tomo lewat radio (Siroj dalam Ubaid dan Bakir, 2015a:8).

Sedangkan A. Helmy Faishal Zaini dalam buku bukunya berjudul Nasionalisme

Kaum Sarungan, menuliskan:

Pada tanggal 22 Oktober 1945 adalah momentum yang sangat bersejarah bagi bangsa Indonesia umumnya dan bagi kalangan santri dan nahdliyin khususnya. Hari itu sejarah mencatat, bertempat di kantor
Hoofd Bestuur Nahdlatoel Oelama (HBNU) di Jalan Bubutan, Surabaya, Jawa Timur, ulama-ulama dari Jawa dan Madura yang berkumpul untuk bermusyawarah dan dipimpin langsung oleh Rais Akbar K.H. Hasyim Asy'ari mengeluarkan fatwa monumental yang kemudian hari kita kenal dengan sebutan Fatwa Resolusi Jihad... (A. Helmy Faishal Zaini, 2018:7475).

Data teks visual film dan data teks historiografi di atas menceritakan adegan ketika Brigadir Jenderal Mallaby pimpinan tentara Sekutu dengan pasukan Inggris mendarat di pantai luar Surabaya. Sementara itu, di Pondok Pesantren Tebuireng, K.H. Hasyim Asy'ari menerima tamu utusan dari Bung Karno yang menanyakan fatwa apa hukumnya membela tanah air, bukan membela agama. K.H. Hasyim Asy'ari kemudian mengundang para kiai-kiai NU untuk bertemu dan membahas perihal permohonan fatwa dari Bung Karno. Di dalam pertemuan tersebut, K.H. Hasyim Asy'ari menyampaikan kedatangan utusan Bung Karno yang menanyakan apa hukumnya membela tanah air. Hukum membela negara dan melawan penjajah adalah fardhu ain bagi setiap muslimin yang berada pada qashar shalat terdapat kaum penjajah maka perang melawan penjajah adalah jihad fisabilillah. Oleh karena itu, umat Islam yang mati dalam peperangan itu adalah sahid. Mereka yang mengkhianati perjuangan umat Islam 
Vol.10 No.2 Juli 2019

dengan memecah-belah persatuan dan menjadi kaki tangan penjajah wajib hukumnya dibunuh. Di dalam rapat di kantor GP Anshor, Bubutan, Surabaya akhirnya Kiai Hasyim Asy'ari mengeluarkan Fatwa Jihad yang kemudian dikenal dengan istilah Resolusi Jihad tanggal 22 Oktober 1945. Resolusi Jihad pun disebarkan ke masyarakat, salah satunya melalui Koran Kedaulatan Rakyat.

Beberapa sumber teks historiografi menuliskan peristiwa lahirnya Resolusi Jihad pada tanggal 22 Oktober 1945 dan kemudian oleh Presiden Joko Widodo ditetapkan sebagai Hari Santri melalui Keputusan Presiden Nomor 22 Tahun 2015 (Keppres No. 22/2015) tentang Hari Santri. Resolusi Jihad inilah yang 18 hari kemudian membakar semangat kepahlawanan arek-arek Surabaya dan sekitarnya pada 10 Nopember 1945 yang sangat heroik dan bersejarah. Semangat Resolusi Jihad dilandasi oleh semangat perlawanan terhadap segala bentuk penjajahan dan penindasan. Diktum hubbul wathan minal iman adalah diktum yang dicetuskan yang menumbuhkan semangat arek-arek Suroboyo untuk menghalau penjajah yang dimotori oleh Nederlandsch Indie Civil Administratie (NICA) pada saat itu (Zaini, 2018: 75).

Fakta sejarah lain dalam historiografi menunjukkan penyebaran Resolusi Jihad tidak saja dilakukan melalui radio oleh Bung Tomo, melainkan juga diberitakan melalui koran Kedaulatan Rakyat (KR). Koran KR edisi Jumat 26 Oktober 1945 memberitakan tuntutan organisasi keagamaan terbesar di Indonesia Nahdlatul Ulama (NU) agar pemerintah mengambil tindakan kehadiran kembali Belanda di Indonesia yang membonceng tentara sekutu. Di koran KR, tuntutan yang dikenal sebagai Resolusi Jihad tersebut berada di halaman 1 bagian bawah dengan judul "Toentoetan Nahdlatoel Oelama kepada Pemerintah Republik'. Koran Kedaulatan Rakyat yang lahir 27 September 1945 merupakan koran perjuangan, karena saat itu menjadi salah satu media propaganda mempertahankan kemerdekaan. Koran KR memuat resolusi tersebut tanggal Jumat Legi, 26 Oktober 1945 ("krjogja." 2016). Fakta sejarah tersebar-luasnya Fatwa dan Seruan Jihad tahun 1945 tidak dapat lepas dari peranan media massa kala itu. Peranan ini menjadi kian penting, karena media lokal di daerahdaerah yang tidak sepaham dengan pihak kolonial Sekutu, termasuk yang berkedudukan di Surabaya, telah banyak yang di-bredel. Pemberitaan Resolusi Jihad di Kedaulatan Rakyat Yogyakarta saat itu dilatarbelakangi oleh tidak terbitnya Harian Suara Asia di Surabaya yang berafiliasi dengan Pemerintahaan Dai Nippon setelah Nagasaki-Hiroshima dibom dan kekalahan Jepang atas Sekutu (Hakim, 2016).

Adegan dalam film tentang kedatangan Sekutu di Surabaya yang 


\section{CAPTURE}

dipimpin oleh Brigadir Jenderal AWS Mallaby dan lahirnya Resolusi Jihad pada tanggal 22 Oktober 1945 oleh Kiai Hasyim Asy'ari dihasilkan pada Rapat Besar Konsul-Konsul Nahdlatul Ulama (NU) seJawa dan Madura, 21-22 Oktober di Surabaya, Jawa Timur, dalam perspektif kajian adaptasi (alih wahana) merupakan transposisi dari medium teks narasi sejarah historiografi ke medium teks audiovisual film. Data teks visual dan data teks historiografi menunjukkan terjadinya transposisi, yaitu pergeseran medium dari teks sejarah ke film. Transposisi dari pergeseran realitas fakta ke fiksi, dari catatan sejarah atau biografi ke narasi atau drama fiksi. Film biopik Sang Kiai ini dalam praktik produksinya merupakan film dokumenter sebagai hasil dari rekonstruksi dan interpretasi sineas atas biografi sejarah tokoh K.H. Hasyim Asy'ari.

Berdasar pada data teks visual film dan data teks historiografi serta analisis di atas dapat disimpulkan adanya hubungan rekonstruksi referensial. Relevansi tekstual antara kedua data yang mengarah kepada konsepsi rekonstruksi adegan peristiwa yang melibatkan tokoh dan waktu terjadinya peristiwa, tampak pada layar film Sang Kiai. Antara K.H. Hasyim Asy'ari sebagai pelaku sejarah (tokoh), periode atau waktu peristiwa tentang keluarnya Resolusi Jihad, dan tempat atau lokasi peristiwa di Surabaya maupun jalinan peristiwanya menunjukkan adanya pola adaptasi (alih wahana) yang mengacu pada teks historiografi. Hal itu menunjukkan terjadinya transposisi dari teks narasi historis menjadi medium produk audiovisual film Sang Kiai. Dengan demikian, terdapat hubungan relevansi yang membuktikan adanya alih wahana atau adaptasi pada sekuen adegan tersebut dan terjadinya transformasi bentuk medium dari teks narasi sejarah ke bentuk teks audiovisual film dokudrama.

Rekonstruksi referensial dalam produksi film Sang Kiai, setidaknya menghadirkan dan menunjukkan kepada penonton tentang kebenaran sejarah peran santri dan ulama yang sangat besar dalam sejarah berdirinya Republik Indonesia serta kemerdekaan Indonesia, khususnya dalam pertempuran Surabaya. Realitas filmis yang kontradiktif dan memberikan alternatif sudut pandang sejarah dari narasi besar sejarah Indonesia semasa Orde Baru ataupun Orde Lama tersubordinasikan oleh kisah heroisme militer serta dominasi dari sosok pimpinan politik nasional semasa revolusi kemerdekaan. Rekaman sejarah keterlibatan para ulama dan santri dalam peristiwa pertempuran Surabaya inilah yang tidak pernah muncul dalam narasi besar pengetahuan warga negeri ini. Untuk itu, momentum Resolusi Jihad Kiai Hasyim Asy'ari serta kontribusi Laskar Hisbullah yang beranggotakan kalangan santri perlu dijadikan sebagai penanda sejarah untuk kebangkitan santri (Siroj dalam Ubaid dan 
Vol.10 No.2 Juli 2019

Bakir, 2015b,58).

\section{SIMPULAN}

Film biopik Sang Kiai mengidentifikasikan keberadaan teks historiografi menjadi referensi penting terkait dengan metode produksi film. Deskripsi teks historiografi merupakan komoditas utama dalam film biopik. Hal ini disebabkan oleh adanya relevansi antara teks historiografi dengan teks visual film dan teks naratif film melalui interpretasi adaptasi (alih wahana) pada sejarah biografi K.H. Hasyim Asy'ari. Momentum puncak-puncak peristiwa besar yang dialaminya sebagai bagian dari esksitensi sejarah K.H. Hasyim Asy'ari yang kemudian dihadirkan oleh filmmaker ke dalam film Sang Kiai melalui struktur naratif dan struktur dramatik film.

Konten film Sang Kiai mengandung pola adaptasi (alih wahana), yaitu terjadi pola transposisi yang menunjuk pada pergeseran medium dari teks narasi fakta sejarah biografi dari $\mathrm{KH}$. Hasyim Asy'ari ke medium teks film dokudrama Sang Kiai. Hal ini menunjukkan perubahan atau pergeseran medium karena pengaruh adaptasi (alih wahana) menandakan terjadinya proses rekonstruksi referensial, yaitu terjadinya transposisi dari teks narasi fiksi ke bentuk medium teks audiovisual film. Hal ini dilatarbelakangi oleh alasan dari hasil analisis yang telah dilakukan: Pertama, terdapat relevansi antara data teks visual dan data teks historiografi yang mengarah pada konsepsi rekonstruksi adegan peristiwa yang bersumber dari penulisan fakta sejarah. Adegan dalam konten film memiliki kesesuaian dengan fakta kebenaran sejarah yang bersumber dari teks historiografi (penulisan sejarah). Adegan peristiwa yang melibatkan tokoh dan waktu terjadinya peristiwa sejarah, mengacu pada referensi sejarah, yaitu historiografi biografi dari para sejarawan yang menuliskan sejarah biografi dari K.H. Hasyim Asy'ari. Filmmaker menjadikannya sebagai referensi untuk melakukan rekonstruksi adegan dalam layar film.

Kedua, adegan-adegan yang merupakan teks filmis merupakan bentuk dari rekonstruksi. Hal ini tampak pada adegan yang merepersentasikan tokoh (pelaku peristiwa), tempat terjadinya peristiwa, dan waktu atau periode dari peristiwa fakta sejarah pada diri tokoh K.H. Hasyim Asy'ari, dengan mengacu pada definisi arti representasi (to re-present) dalam konteks tulisan sejarah atau biografi dan ketentuanketentuan baku dalam produksi film dokudrama sejarah, yaitu: periode (waktu peristiwa sejarah), tempat (lokasi peristiwa sejarah), dan pelaku sejarah.

\section{DAFTAR ACUAN}

Buku:

A. Helmy Faishal Zaini. 2018. Nasionalisme Kaum Sarungan. Jakarta: Kompas.

Ali M. Haidar. 1998. Nahdatul Ulama dan Islam di Indonesia. Jakarta: Gramedia Pustaka Utama.

Ambo Upe dan Damsid, Asas-Asas Multiple Researches (dari Norman 


\section{CAPTURE}

K. Denzin hingga John W. Creswell dan Penerapannya), Yogyakarta: Tiara Wacana, 2010.

Bangun Ayawaila, Muhlisiun Afandi, Wibawa, dan Siagian. 2013. Penyemaian Industri Perfilman Indonesia, Jakarta: FFTV-IKJ Press.

Denzin, Norman dan Lincoln, Yvonna S. 1994. Entering the Field of Qualitative Research, CA: Sage Publication.

Denzin, Norman K dan Lincoln, Yvonna S (Ed). 2011. The Sage Handbook of Qualitative Research 1, terj, Dariyatno. Yogyakarta: Pustaka Pelajar.

Gerzon R. Ayawaila. 2008. Dokumenter dari Ide sampai Produksi, Jakarta: FFTV-IKJ Press, 2008.

Giles, Judy dan Middleton, Tim. 1999. Studying Culture: A Practical Introduction. Oxford: Blackwell Publishers.

Helius Sjamsuddin. 2016. Metodologi Sejarah, Yogyakarta: Ombak.

Hutcheon, Linda. 2006. A Theory of Adaptation, London and New York: Routledge.

Indira Ardanareswari. 2018. Seks dalam Layar: Politik Seksual dalam Industri Film Indonesia 1950-1992. Yogyakarta: Dialog Pustaka.

Lathiful Khuluq. 2007. Fajar Kebangunan Ulama Biografi K.H. Hasyim Asy'ari. Yogyakarta: LKIS.

Palmer, Richard E. 2016. Hermeneutika Teori Baru Mengenai Interpretasi, terj. Musnur Hery dan Damanhuri Muhammad. Yogyakarta: Pustaka Pelajar.

Rachmah Ida. 2014. Metode Penelitian Studi Media dan Kajian Budaya, Jakarta: Prenada Media Group.

R.B. Armantono dan Suryana Paramita. 2017. Penulisan Skenario Film Panjang, Cetakan Kedua, Jakarta:
FFTV IKJ

Said Agil Siroj. 2015a. "Resolusi Jihad, Melawan Lupa". Dalam Abdullah Ubaid dan Mohammad Bakir (ed). Nasionalisme dan Islam Nusantara. Jakarta: Kompas.

Said Agil Siroj. 2015b. "Menjaga Marwah Ulama". Dalam Abdullah Ubaid dan Mohammad Bakir (ed). Nasionalisme dan Islam Nusantara. Jakarta: Kompas.

Teuku Ibrahim Alfian. 2005. "Paradigma dalam Merekonstruksi Suatu Fenomena Sejarah". Dalam Seni Pertunjukkan Indonesia: Menimbang Pendekatan Emik Nusantara. Waridi dan Bambang Murtiyoso (ed). Surakata: The Ford Foundation dan Program Pendidikan Pascasarjana Sekolah Tinggi Seni Indonesia Surakarta.

Zuhairi Misrawi. 2010. Hadratussyaikh Hasyim Asy'ari Moderasi, Keumatan, dan Kebangsaan. Jakarta: Kompas.

\section{Jurnal Ilmiah:}

Nurida Ismawati dan Warto. 2016. "NilaiNilai Nasionalisme Santri dalam Film Sang Kyal". Jurnal ATTabsyir: Jurnal Komunikasi Penyiaran Islam, Vol. 4, No. 2 Desember 2016: 361-390.

Pupu Saeful Rahmat. 2009. "Penelitian Kualitatif." Jurnal EQUILIBRIUM, Vol. 5, No. 9 Edisi (Januari-Juni 2009): 1-8.

Rosenstone, Robert A. 1995. "The Historical Film as Real History", Journal Film-Historia, Vol. V, No.1 (1995): 5-23.

Sandy Allifiansyah. 2017. "Oposisi Biner Kesejarahan Indonesia Periode Revolusi Fisik (1945-1949) dalam Film Seogija (2012) dan Sang Kiai (2013)", Semiotika: Jurnal Komunikasi, Vol. 11, No. 1 (2017): 163-200. 


\section{Internet:}

Abdul Mun'im DZ. 2012. "Kisah Tebuireng, dari Mbah hasyim hingga Gus Dur". diakses pada tanggal 2 Desember

2018.http://www.nu.or.id/post/read/ 38786/kisah-tebuireng-dari-mbahhasyim-hingga-gus-dur.

Krjoga,2016.http://krjogja.com/web/news/re ad/13802/KR_Memuat_Resolusi_Ji had_NU diakses tanggal 13

Desember 2018

\section{Narasumber:}

I.G.P. Wiranegara, 61 tahun, sutradara film dokumenter. Akademi Televisi Indonesia (ATVI), Jakarta. Jl. Margasari II B No. A-49, Bumi Asri Margaasih, Bandung.

Marselli Sumarno, 63 tahun, pengamat dan praktisi film serta dosen Fakultas Film Televisi Institut Kesenian Jakarta (IKJ), Kompleks TIM, JI. Cikini Raya No. 73, RT. 08/Rw. 2, Cikini, Menteng, Jakarta Pusat.

Mohamad Ariansah, 45 tahun, pengamat film dan dosen Fakultas Film Televisi Institut Kesenian Jakarta (IKJ), Kompleks TIM, Jl. Cikini Raya No. 73, RT. 08/Rw. 2, Cikini, Menteng, Jakarta Pusat. 